\title{
Usage Patterns of Sacroiliac Joint Injections - A Comparative Evaluation of Pre and Post Affordable Care Act in Medicare Population
}

\author{
Maanasa V. Manchikanti ${ }^{1}$, Laxmaiah Manchikanti, MD $^{2}$, Alan D. Kaye, MD, PhD ${ }^{3}$, \\ Vidyasagar Pampati, MSc ${ }^{2}$, and Joshua A. Hirsch, MD ${ }^{4}$
}

Background: The sacroiliac joints (SIJ) have been implicated as highly prevalent, pervasive, expensive, causes of chronic low back pain. The utilization of SIJ injections is escalating. A recent analysis demonstrated a reversal of growth of utilization patterns of interventional techniques post passage of the Affordable Care Act (ACA). Bearing that in mind, SIJ injections along with facet joint interventions seem to have increased modestly in that same period.

Study Design: Analysis of growth patterns of SIJ injections from 2000 to 2016 with comparative analysis of pre- and post- ACA.

Objectives: To assess utilization patterns of SIJ injections from 2000 to 2016.

Methods: The Centers for Medicare and Medicaid Services (CMS) Physician/Supplier Procedure Summary (PSPS) Master dataset was utilized in this analysis.

Results: The results of the evaluation from 2000 to 2016 showed, $11.7 \%$ increase from 2009 to
2016 , with an annual increase of $1.6 \%$ per 100,000 Medicare population compared to an increase of $299.8 \%$ from 2000 to 2009 with annual increase of $16.6 \%$.

Limitations: The limitations of this study included a lack of inclusion of Medicare Advantage patients and the possibility that state claims data may include claims from other states. As with all claims based data analyses, this study is retrospective and thus potentially limited by bias. Finally, patients who are self or commercially insured are not part of the dataset.

Conclusions: Study shows dampened increase in utilization patterns of SIJ injections from 2009 to 2016 as compared with a like time period prior.

Key words: Chronic spinal pain, low back pain, sacroiliac joint arthritis, interventional techniques, interventional pain management, sacroiliac joint injections
Due to continued increases in utilization patterns of various modalities of treatments in managing chronic low back pain, multiple efforts have been made to reduce the escalating use of various interventions $(1,2)$. The Affordable Care Act $(A C A)$ sought to transform healthcare. In the surrounding years, multiple other regulations, including continued efforts to

From : ${ }^{1}$ University of Kentucky, Lexington KY; ${ }^{2}$ Pain Management Center of Paducah, Paducah, KY; ${ }^{3}$ LSU Health Science Center, New Orleans, LA; ${ }^{4}$ Massachusetts General Hospital and Harvard Medical School, Boston, MA and Neiman Health Care Policy Institute, Reston, VA

Author for correspondence: Laxmaiah Manchikanti, MD

Address: Pain Management Center of Paducah, 2831 Lone Oak Rd, Paducah, KY 42003

E-mail:drlm@thepainmd.com reform health care in the United States have sought to modify the delivery of care in the U.S. (3-19). Among the many modalities utilized in managing chronic low back pain, interventional techniques and complex surgical interventions take center stage, seemingly despite the utilization of multiple other modalities, most notably extensive use of opioids $(1,2,20-29)$. The ACA and several other regulations were established with 3 primary goals of increasing the number of insured, improving the quality of care, and controlling health care costs (3-8). However, based on extensive evaluation it appears that while the ACA has increased the number of insured it may have decreased coverage for medical services leading to a reduction in access and potentially quality for some (3-8). 
The impact of chronic pain on health care and economy is enormous $(1,2,27,28)$. Dielman et al $(1,2)$ have estimated spending of $\$ 87.6$ billion in managing low back and neck pain, accounting for the third highest amount of various disease categories with the dollars spent continuing to increase. Other studies have shown increasing burden of low back pain on health care with chronic disability $(1,2,27,28)$.

Interventional techniques, including sacroiliac joint (SIJ) injections, are one of the commonly utilized modalities of treatments in managing low back pain. There exists debates regarding the appropriateness of utilization, treatment effectiveness and cost utility (10,11,25-27,29-53). A previous assessment of SIJ injections from 2000 to 2014 (26) demonstrated significant increases in utilization patterns from 2000 to 2014 of $316.9 \%$, with an annual increase of $10.7 \%$ per 100,000 Medicare population. The increases were constant through 2006 and significant, whereas since 2007 there have been declines in growth. The increases in utilization patterns were higher than epidural injections, but similar to facet joint interventions $(26,27)$. A recent analysis of growth patterns of interventional techniques from 2000 to 2016, with comparative analysis of utilization patterns before and after enactment of ACA demonstrated interesting results with significant decreases for epidural and adhesiolysis procedures, disc procedures and other types of nerve blocks from 2009 to 2016 with slow increase for facet joint interventions and SIJ blocks, with overall decrease in utilization patterns of $3.9 \%$ with an annual decline of $0.6 \%$ from 2009 to 2016 per 100,000 Medicare population $(24,54,55)$. While it appears that modest rather than explosive growth continues to be present, the comparative analysis prior to and after passage of the ACA has not been performed. This analysis is undertaken to assess utilization patterns of SIJ injections before and after 2009.

\section{METHODS}

This assessment was performed with the public use file with non-identifiable, which is non-attributable, and non-confidential, available through Centers for Medicare and Medicaid Services (CMS) database (56). The study was performed using Strengthening the Reporting of Observational Studies (STROBE) in epidemiology guidance (57), without seeking approval from the Institutional Review Board.

\section{STUDY DESIGN}

This assessment was designed to evaluate usage or utilization patterns and variables of SIJ injections from 2000 to 2016 in the Medicare fee-for-service (FFS) population in the United States.

\section{SETTING}

The National Database of Speciality Usage Data files from CMS in the FFS Medicare population in the United States (56).

\section{Participants}

The data from all the participants form the database of FFS Medicare recipients were utilized from 2000 to 2016.

\section{Variables}

Multiple variables were assessed including usage patterns of SIJ injections from 2000 to 2016, from 2000 to 2009, and 2009 to 2016.

The Current Procedural Terminology (CPT) code for SIJ injections (CPT 20670 and G20670 for physician, hospital outpatient department (HOPD), and ambulatory surgery center (ASC) was utilized which has been in effect during the study period.

The data were also assessed based on the place of service identifying HOPD, ASC, and a non-facility setting or office setting.

\section{Data Sources}

The analyzed data were obtained from the CMS Physician/Supplier Procedure Summary Master Data file from 2000 to 2016 (56). These data consisted of all FFS Medicare participants.

\section{Measures}

The usage pattern analysis included all allowed services configured by taking services submitted minus services denied and services with zero payments. The rate was calculated per 100,000 Medicare beneficiaries. 


\section{Bias}

The American Society of Interventional Pain Physicians (ASIPP) a not-for-profit organization, purchased the data. The study was also conducted with the internal resources of the primary authors' practice without external funding.

\section{Study Size}

The study size is large with inclusion of all patients under Medicare FFS undergoing SIJ injections in all settings from 2000 to 2016 .

\section{Data Compilation}

The data was compiled by using Microsoft Access 2010 and Microsoft Excel 2010 (Microsoft Corporation, Redmond, Virginia).

\section{RESULTS}

\section{Participants}

Participants in this assessment included all FFS Medicare recipients from 2000 to 2016.

\section{Utilization Characteristic}

Table 1 shows frequency of SIJ injections in Medicare population from 2000 to 2016 with comparative data from 2000 to 2009 and 2009 to 2016. Comparative analysis showed SIJ injections increased $299.8 \%$ from 2000 to 2009 with an annual increase of $16.6 \%$, whereas the increases were milder per 100,000 Medicare population from 2009 to 2016 with total increase of $11.7 \%$ and an annual increase of $1.6 \%$.

Figure 1 shows relative declines of various interventional techniques compared to SIJ blocks with comparison of lumbar facet joint blocks, lumbar epidural injections, disc procedures and other types of nerve blocks, in comparison to all interventional techniques.

\section{Utilization Characteristic by State}

Utilization characteristics in various states was analyzed based on Medicare Administrative Contractors (MACs) jurisdictions.

As shown in Table 2, based on MACs jurisdictions from 2009 to 2016, First Coast Services covering Florida and Cahaba covering Alabama, Georgia, Tennessee showed $1 \%$ and $1.4 \%$ reductions in utilization per year with a total of $7 \%$ and $9 \%$ decrease overall. All other carriers showed increases ranging from $1.5 \%$ for WPS, $2.3 \%$ for Palmetto, $2.8 \%$ for CGS, $3.2 \%$ for Novitas, $3.3 \%$ for NGS, and, finally, the highest increases noted for Noridian with $4.3 \%$ annually or $34 \%$ from 2009 to 2016 . Noridian led policies removed Local Coverage Determination (LCD) for SIJ injections (58-60). The increases are similar to other procedures, which have shown higher rates of increases or lower rates of declines in Noridian states compared to others (24-27), except for adhesiolysis (55), wherein Noridian led the noncoverage policy. The data also showed major increases in Noridian states as high as $21.1 \%$ for Alaska, $9.8 \%$ for Wyoming, $8.9 \%$ for North Dakota, $8.1 \%$ for Utah, $8 \%$ for Oregon, and $7 \%$ for Arizona. Only one Noridian state - Montana, showed a decline of $2.2 \%$. Multiple other states also showed increases in other MACs with over $6 \%$ including the states of Connecticut, Delaware, Oklahoma, Colorado, Maine, Massachusetts and District of Columbia. The majority of the declines were observed in Tennessee, Rhode Island, with minor declines in New Hampshire, Montana, and Florida. The assessment of usage patterns of SIJ injections from 2000 to 2009 showed escalating usage with annual increases of $16.6 \%$ and overall increase of $299 \%$, whereas from 2009 to 2016 , overall increases were $11.7 \%$ with an annual increase of $1.6 \%$ per 100,000 Medicare population. Overall, the study showed dampened increase in utilization patterns of SIJ injections from 2009 to 2016.

\section{DISCUSSION}

The comparative assessment of utilization data of SIJ injections for low back and lower extremity pain in Medicare FFS population from 2000 to 2016 showed dramatic shifts from 2009 to 2016 after enactment of ACA and other regulations as compared with the period of 2000 to 2009. The data shows that there was a significant increase of utilization of SIJ injections from 2000 to 2009 with 299.8\% per 100,000 Medicare population with annual increase of $16.6 \%$, which was described as an explosive increase, but with modest growth from 2009 to 2016 with total increase of $11.7 \%$ and at an annual increase of $1.6 \%$. Consequently, while SIJs still show continuing increase in utilization, it is notably below growth of elderly population of annual growth of $3.2 \%$ and Medicare participants of $3 \%$. 


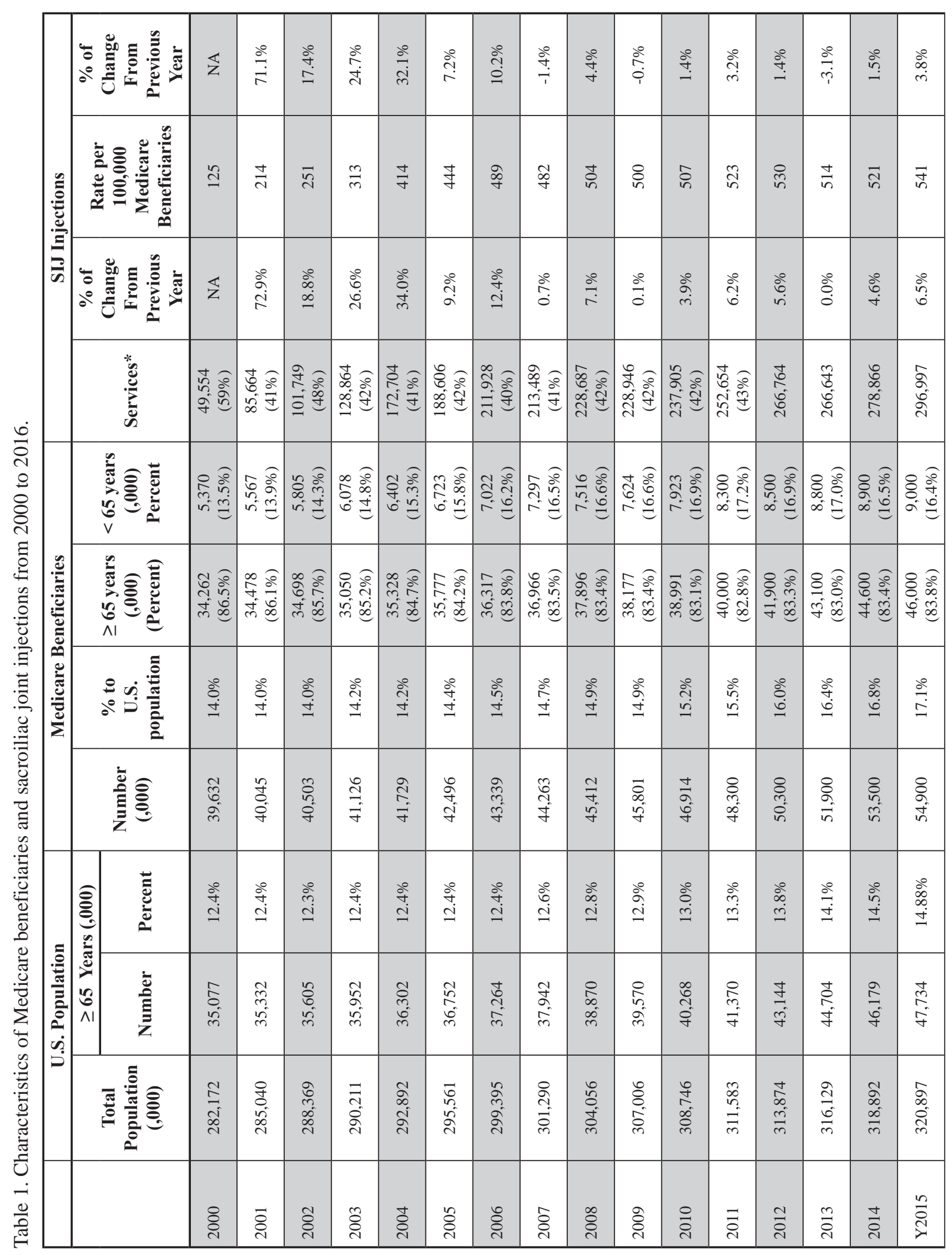




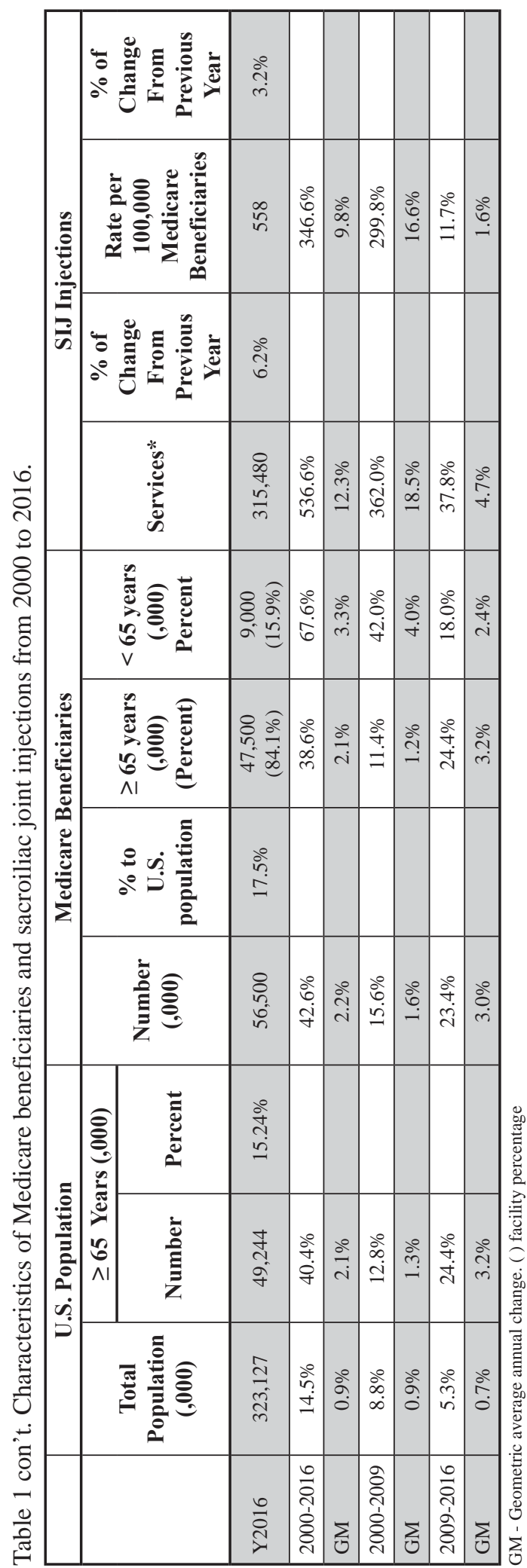

These growth patterns are similar in earlier years compared to the previous publications; however, there is a significant reversal of growth patterns even though there is no net decline from 2009 to 2016 . However, while the increases appear to be similar to facet joint interventions during these periods they contrast with decreases of epidural and adhesiolysis procedures as well as disc procedures and other types of nerve blocks $(24,54)$ as shown in Fig. 1.

Multiple LCDs were spearheaded by Noridian presumably at least in part to diminish utilization. Noridian did not put a specific policy for SIJ injections into place. Despite the LCDs, Noridian states increased SIJ injections utilization of $4.3 \%$ annually compared to a national rate of $3.2 \%$ from 2009 to 2016 (58-60). In fact, other MACs that do not utilize Noridian policies have shown smaller increases or decreases of utilization of SIJ injections; $2.8 \%$ for CGS and reduction in 1\% for First Coast Services. Only one MAC showed decline in usage patterns with $1.4 \%$ annual, for Cahaba, mainly based on decline in utilization of SIJ injections from Tennessee. In addition, statewide data also showed extensive increases at an annual rate of $21.1 \%$ for Alaska, $9.8 \%$ for Wyoming, 8.9\% for North Dakota, 8.1\% for Utah, 8\% for Oregon, $7 \%$ for Arizona, $5.9 \%$ for Idaho, and $4.7 \%$ for Nevada. The price changes with fluctuating reimbursement pattern starting in 2014 with significant reductions in payments and also bundling of fluoroscopy into the procedure have contributed in decline (11,12,61-63). In 2009 , the stimulus act initiated multiple regulations and a focus on decreasing utilization with increasing regulatory aspects (64). In addition, as compared with prior eras, there was exceptional expansion of regulatory atmosphere with enactment of multiple other regulations of quality performance, meaningful use, and cost reductions (3-19). Further, multiple changes related to code definition, lack of LCDs resulting in non-coverage policies, concurrent with reduction of reimbursement have influenced utilization patterns. These changes can have the impact of reducing access for Medicare and other beneficiaries $(3,8,11,12,24-27,65,66)$.

SIJ injections are controversial with respect to appropriate utilization, overuse, misuse, abuse, fraud, coupled with claims of lack of evidence of effectiveness, medical necessity, and indications (44). Any treatment requires proper utilization with appropriate use with determination of medical necessity and indications (60). Beyond 


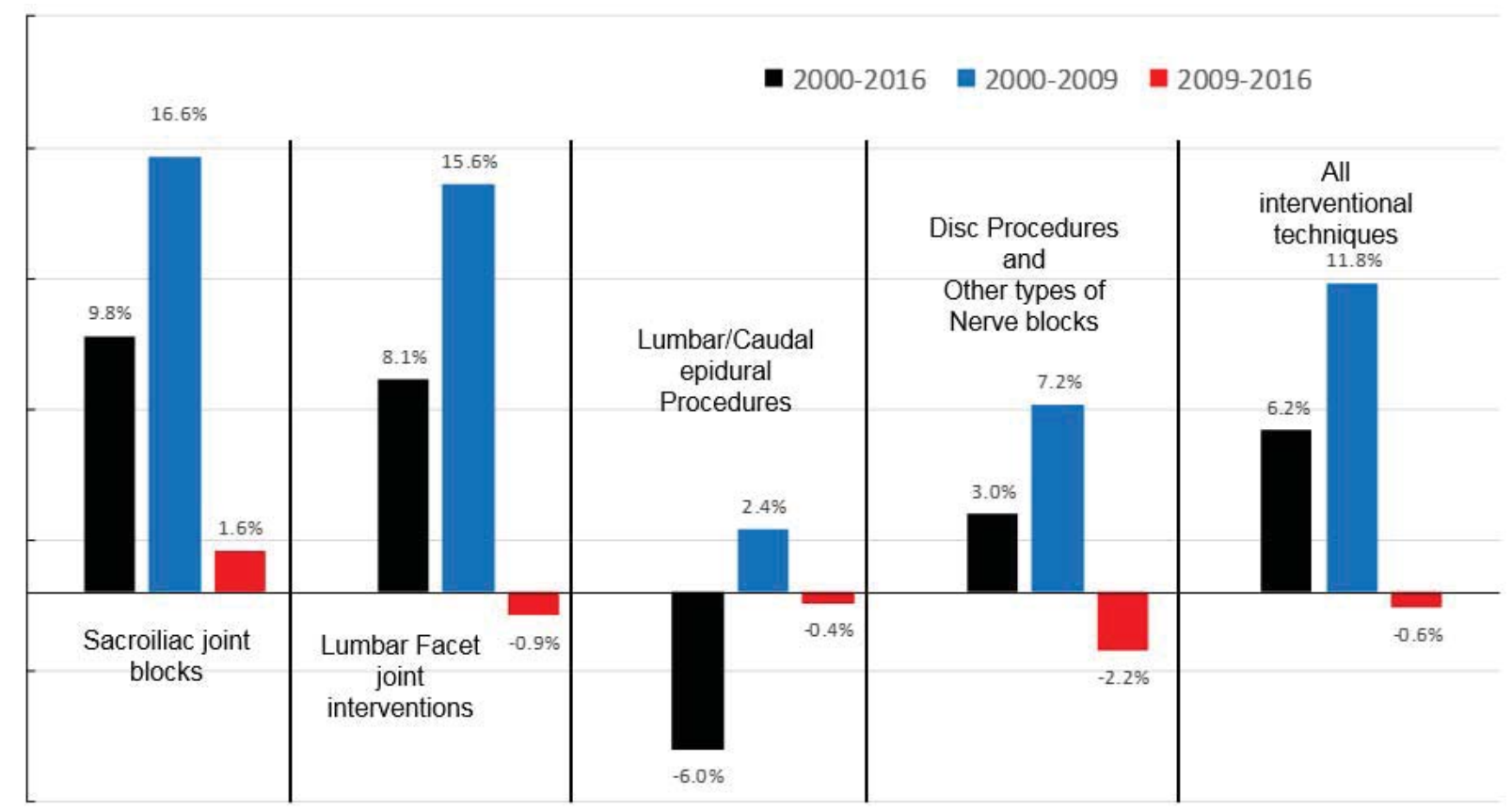

Fig. 1. Comparative analysis of sacroiliac joint blocks, lumbar facet joint interventions, lumbar/caudal epidural procedures, disc procedures and other types of nerve blocks, all interventional techniques annual change.

Table 2. Utilization of sacroiliac joint intervention rates by 2016 Medicare Carrier from 2009-2016 in Medicare population.

\begin{tabular}{|l|c|c|c|c|c|c|c|c|c|c|c|}
\hline $\begin{array}{c}\text { 2016 Medicare } \\
\text { Carrier }\end{array}$ & State & R2009 & R2010 & R2011 & R2012 & R2013 & R2014 & R2015 & R2016 & Change & GM \\
\hline Cahaba & Alabama & 617 & 836 & 809 & 850 & 745 & 695 & 768 & 805 & $30 \%$ & $3.9 \%$ \\
\hline & Georgia & 716 & 669 & 803 & 812 & 676 & 691 & 735 & 789 & $10 \%$ & $1.4 \%$ \\
\hline & Tennessee & 895 & 900 & 1101 & 845 & 568 & 455 & 417 & 448 & $-50 \%$ & $-9.4 \%$ \\
\hline & Cahaba Total & 750 & 792 & 905 & 833 & 658 & 613 & 637 & 680 & $-9 \%$ & $-1.4 \%$ \\
\hline CGS & Kentucky & 783 & 865 & 845 & 925 & 948 & 1071 & 1017 & 1139 & $46 \%$ & $5.5 \%$ \\
\hline & Ohio & 557 & 535 & 513 & 537 & 541 & 574 & 566 & 598 & $7 \%$ & $1.0 \%$ \\
\hline & CGS Total & 621 & 630 & 608 & 648 & 659 & 717 & 695 & 753 & $21 \%$ & $2.8 \%$ \\
\hline First Coast & Florida & 867 & 792 & 806 & 789 & 741 & 729 & 772 & 807 & $-7 \%$ & $-1.0 \%$ \\
\hline NGS & Connecticut & 290 & 287 & 368 & 459 & 504 & 530 & 558 & 570 & $97 \%$ & $10.1 \%$ \\
\hline & Illinois & 386 & 402 & 366 & 427 & 425 & 431 & 482 & 492 & $27 \%$ & $3.5 \%$ \\
\hline & Maine & 300 & 337 & 354 & 456 & 541 & 450 & 535 & 471 & $57 \%$ & $6.6 \%$ \\
\hline & Massachusetts & 353 & 401 & 453 & 494 & 482 & 491 & 500 & 531 & $50 \%$ & $6.0 \%$ \\
\hline & Minnesota & 276 & 324 & 315 & 330 & 307 & 284 & 287 & 321 & $16 \%$ & $2.2 \%$ \\
\hline & New Hampshire & 637 & 654 & 662 & 720 & 659 & 672 & 610 & 539 & $-15 \%$ & $-2.3 \%$ \\
\hline & New York & 250 & 206 & 223 & 261 & 296 & 315 & 359 & 315 & $26 \%$ & $3.3 \%$ \\
\hline
\end{tabular}




\begin{tabular}{|c|c|c|c|c|c|c|c|c|c|c|c|}
\hline $\begin{array}{l}2016 \text { Medicare } \\
\text { Carrier }\end{array}$ & State & R2009 & R2010 & R2011 & R2012 & R2013 & R2014 & R2015 & R2016 & Change & GM \\
\hline & Rhode Island & 1173 & 1217 & 1194 & 1012 & 852 & 801 & 771 & 689 & $-41 \%$ & $-7.3 \%$ \\
\hline & Vermont & 337 & 385 & 400 & 400 & 416 & 454 & 497 & 476 & $41 \%$ & $5.0 \%$ \\
\hline & Wisconsin & 438 & 454 & 460 & 501 & 526 & 449 & 465 & 515 & $18 \%$ & $2.3 \%$ \\
\hline & NGS Total & 345 & 348 & 358 & 400 & 412 & 409 & 440 & 434 & $26 \%$ & $3.3 \%$ \\
\hline \multirow[t]{13}{*}{ Noridian } & Alaska & 139 & 135 & 180 & 271 & 268 & 270 & 861 & 531 & $282 \%$ & $21.1 \%$ \\
\hline & Arizona & 408 & 441 & 441 & 498 & 577 & 643 & 617 & 657 & $61 \%$ & $7.0 \%$ \\
\hline & California & 285 & 299 & 290 & 293 & 280 & 303 & 327 & 327 & $14 \%$ & $1.9 \%$ \\
\hline & Idaho & 414 & 391 & 419 & 469 & 474 & 568 & 607 & 618 & $49 \%$ & $5.9 \%$ \\
\hline & Montana & 343 & 264 & 305 & 284 & 268 & 267 & 244 & 293 & $-14 \%$ & $-2.2 \%$ \\
\hline & Nevada & 390 & 401 & 456 & 443 & 485 & 468 & 526 & 537 & $37 \%$ & $4.7 \%$ \\
\hline & North Dakota & 474 & 547 & 526 & 651 & 773 & 874 & 833 & 861 & $82 \%$ & $8.9 \%$ \\
\hline & Oregon & 215 & 239 & 261 & 283 & 288 & 369 & 402 & 369 & $72 \%$ & $8.0 \%$ \\
\hline & South Dakota & 1001 & 997 & 1074 & 1152 & 1127 & 1179 & 1203 & 1290 & $29 \%$ & $3.7 \%$ \\
\hline & Utah & 588 & 660 & 685 & 787 & 708 & 818 & 941 & 1013 & $72 \%$ & $8.1 \%$ \\
\hline & Washington & 225 & 217 & 226 & 214 & 266 & 262 & 298 & 309 & $37 \%$ & $4.6 \%$ \\
\hline & Wyoming & 266 & 262 & 289 & 324 & 434 & 457 & 542 & 511 & $92 \%$ & $9.8 \%$ \\
\hline & Noridian Total & 318 & 331 & 335 & 350 & 360 & 393 & 422 & 426 & $34 \%$ & $4.3 \%$ \\
\hline \multirow[t]{13}{*}{ Novitas } & Arkansas & 543 & 469 & 449 & 470 & 506 & 530 & 608 & 618 & $14 \%$ & $1.9 \%$ \\
\hline & Colorado & 337 & 352 & 383 & 435 & 464 & 502 & 518 & 556 & $65 \%$ & $7.4 \%$ \\
\hline & $\mathrm{DC}$ & 1669 & 1639 & 1795 & 2031 & 2695 & 3017 & 3452 & 3430 & $106 \%$ & $10.8 \%$ \\
\hline & Delaware & 297 & 289 & 486 & 571 & 704 & 675 & 640 & 548 & $85 \%$ & $9.1 \%$ \\
\hline & Louisiana & 303 & 281 & 291 & 291 & 345 & 319 & 363 & 386 & $27 \%$ & $3.5 \%$ \\
\hline & Maryland & 404 & 387 & 376 & 442 & 509 & 517 & 545 & 511 & $26 \%$ & $3.4 \%$ \\
\hline & Mississippi & 592 & 553 & 507 & 507 & 572 & 575 & 677 & 725 & $23 \%$ & $3.0 \%$ \\
\hline & New Jersey & 345 & 349 & 359 & 379 & 421 & 423 & 437 & 461 & $34 \%$ & $4.2 \%$ \\
\hline & New Mexico & 304 & 291 & 327 & 374 & 392 & 367 & 364 & 339 & $11 \%$ & $1.6 \%$ \\
\hline & Oklahoma & 341 & 313 & 438 & 499 & 477 & 493 & 620 & 613 & $79 \%$ & $8.7 \%$ \\
\hline & Pennsylvania & 295 & 316 & 316 & 318 & 349 & 377 & 374 & 390 & $32 \%$ & $4.0 \%$ \\
\hline & Texas & 566 & 505 & 526 & 520 & 502 & 542 & 574 & 573 & $1 \%$ & $0.2 \%$ \\
\hline & Novitas Total & 424 & 404 & 422 & 439 & 465 & 486 & 520 & 530 & $25 \%$ & $3.2 \%$ \\
\hline \multirow[t]{5}{*}{ Palmetto GBA } & North Carolina & 613 & 618 & 673 & 736 & 716 & 717 & 759 & 795 & $30 \%$ & $3.8 \%$ \\
\hline & South Carolina & 708 & 803 & 988 & 1051 & 1034 & 961 & 809 & 777 & $10 \%$ & $1.3 \%$ \\
\hline & Virginia & 563 & 584 & 650 & 571 & 544 & 607 & 638 & 626 & $11 \%$ & $1.5 \%$ \\
\hline & West Virginia & 491 & 429 & 428 & 411 & 424 & 400 & 379 & 476 & $-3 \%$ & $-0.5 \%$ \\
\hline & Palmetto Total & 605 & 626 & 706 & 719 & 704 & 706 & 699 & 711 & $17 \%$ & $2.3 \%$ \\
\hline \multirow[t]{7}{*}{ WPS } & Indiana & 616 & 707 & 800 & 844 & 735 & 796 & 783 & 814 & $32 \%$ & $4.1 \%$ \\
\hline & Iowa & 394 & 431 & 435 & 507 & 517 & 514 & 507 & 577 & $46 \%$ & $5.6 \%$ \\
\hline & Kansas & 550 & 651 & 660 & 637 & 623 & 643 & 657 & 633 & $15 \%$ & $2.0 \%$ \\
\hline & Michigan & 836 & 1025 & 891 & 997 & 919 & 789 & 784 & 798 & $-5 \%$ & $-0.7 \%$ \\
\hline & Missouri & 865 & 850 & 868 & 885 & 908 & 922 & 909 & 934 & $8 \%$ & $1.1 \%$ \\
\hline & Nebraska & 563 & 578 & 539 & 610 & 702 & 878 & 627 & 704 & $25 \%$ & $3.2 \%$ \\
\hline & WPS Total & 709 & 802 & 779 & 838 & 799 & 781 & 761 & 786 & $11 \%$ & $1.5 \%$ \\
\hline
\end{tabular}


that, there is emerging evidence for appropriate diagnosis and treatment of SIJ pain (37-43).

This analysis reconfirms the well-known fact that there have been increases in elderly and Medicare populations. Perhaps less well known, this analysis indicates that there was a decrease in the rate patients enrolled in Medicare with disabilities pre- and post- the ACA. There was an annual growth rate of $2.4 \%$ from 2009 to 2016 as compared with an annual growth rate was $4 \%$ from 2000 to 2009 . This suggests that individuals with disability are being enrolled in Medicaid instead of Medicare post- Medicaid expansion $(67,68)$.

Declining rate of utilization of interventional pain management procedures may be considered as a contributing factor to escalating opioid epidemic (28,46,54,69-72). Multiple attempts have been made from administration officials to curtail the opioid epidemic with promotion of nonopioid interventional techniques $(28,46,69-72)$; however, in contrast to the public perceptions and perceived policies, we believe that the present policies continue to promote the decline of non-opioid techniques (28,30-53).

Limitations of this assessment include lack of inclusion of Medicare Advantage Plans, which constitute approximately $30 \%$ of the population, self and commercially insured plans. However, the present assessment also is expected to apply to Medicare Advantage Plans and other carriers with enhanced implementation of reduction strategies. As with all claims based data reviews, this analysis is retrospective and thus could be influenced by reviewer bias.

\section{CONCLUSION}

The assessment of usage patterns of SIJ blocks from 2000 to 2016 showed a trend with decrease in the rate of increase of utilization from 2009 to 2016. From 2009-2016 there was an annual increase of $1.6 \%$ per 100,000 Medicare population, compared to an annual increase of $16.6 \%$ from 2000 to 2009 . Multiple factors have been attributed to changes in utilization patterns.

\section{Acknowledgments}

The authors wish to thank Bert Fellows, MA, Director Emeritus of Psychological Services, for manuscript review, and Tonie M. Hatton and Diane E. Neihoff, transcriptionists, for their assistance in the preparation of this manuscript. We would like to thank the editorial board of IPM Reports for review and criticism in improving the manuscript.

\section{REFERENCES}

1. Dieleman JL, Baral R, Birger M, Bui AL, Bulchis A, Chapin A, Hamavid H, Horst C, Johnson EK, Joseph J, Lavado R, Lomsadze L, Reynolds A, Squires E, Campbell M, DeCenso B, Dicker D, Flaxman AD, Gabert R, Highfill T, Naghavi M, Nightingale N, Templin T, Tobias MI, Vos T, Murray CJ. US spending on personal health care and public health, 1996-2013. JAMA 2016; 316:2627-2646.

2. Dieleman JL, Squires E, Bui AL, Campbell M, Chapin A, Hamavid H, Horst C, Li Z, Matyasz T, Reynolds A, Sadat N, Schneider MT, Murray CJL. Factors associated with increase in US health care spending, 1996-2013. JAMA 2017; 318:1668-1678.

3. Manchikanti L, Helm S 2nd, Benyamin RM, Hirsch JA. A critical analysis of Obamacare: Affordable care or insurance for many and coverage for few? Pain Physician 2017; 20:111-138.

4. Manchikanti L, Hirsch JA. Repeal and replace of Affordable Care: A complex, but not an impossible task. Pain Physician 2016; 19:E1109-E1113.

5. Bauchner $\mathrm{H}$, Fontanarosa $\mathrm{PB}$. The future of US health care policy. JAMA 2016; 315:1339-1340.

6. Obama B. United States health care reform: Progress to date

and next steps. JAMA 2016; 316:525-532.

7. Bauchner $\mathrm{H}$. The Affordable Care Act and the future of US health care. JAMA 2016; 316:492-493.

8. Cannon MF. Is Obamacare harming quality? (Part 1). Health Affairs Blog, January 4, 2018. www.healthaffairs.org/do/10.1377/ hblog20180103.261091/full/

9. Hirsch JA, Barr R, McGinty G, Nicola GN, Silva III E, Schaefer P, Manchikanti L. Affordable Care 2014: A tale of two boards. J Neurointerv Surg 2014; 6:718-720.

10. Hirsch JA, Leslie-Mazwi TM, Patel AB, Rabinov JD, Gonzalez RG, Barr RM, Nicola GN, Klucznik RP, Prestigiacomo CJ, Manchikanti L. MACRA: Background, opportunities and challenges for the neurointerventional specialist. J Neurointerv Surg 2016; 8:868-874.

11. Manchikanti L, Kaye AD, Hirsch JA. Proposed Medicare physician payment schedule for 2017: Impact on interventional pain management practices. Pain Physician 2016; 19:E935-E955.

12. Manchikanti L, Singh V, Hirsch JA. Facility payments for interventional pain management procedures: Impact of proposed rules. Pain Physician 2016; 19:E957-E984. 
13. Manchikanti L, Hammer M, Benyamin RM, Hirsch JA. Physician Quality Reporting System (PQRS) for interventional pain management practices: Challenges and opportunities. Pain Physician 2016; 19:E15-E32.

14. Hirsch JA, Harvey HB, Barr RM, Donovan WD, Duszak R Jr, Nicola GN, Schaefer PW, Manchikanti L. Sustainable growth rate repealed, MACRA revealed: Historical context and analysis of recent changes in Medicare physician payment methodologies. AJNR Am J Neuroradiol 2016; 37:210-214.

15. Hirsch JA, Leslie-Mazwi TM, Barr RM, McGinty G, Nicola GN, Patel AB, Manchikanti L. The Burwell roadmap. J Neurointerv Surg 2016; 8:544-546.

16. Slavitt A. Our next health care debate. JAMA 2017; 318:12121213.

17. Hirsch JA, Leslie-Mazwi TM, Nicola GN, Bhargavan-Chatfield M, Seidenwurm DJ, Silva E, Manchikanti L. PQRS and the MACRA: Value-based payments have moved from concept to reality. AJNR Am J Neuroradiol 2016; 37:2195-2200.

18. Manchikanti L, Helm S 2nd, Benyamin RM, Hirsch JA. MeritBased Incentive Payment System (MIPS): Harsh choices for interventional pain management physicians. Pain Physician 2016; 19:E917-E934.

19. Hirsch JA, Leslie-Mazwi TM, Barr RM, McGinty G, Nicola GN, Silva E 3rd, Manchikanti L. The bundled payments for care improvement initiative. J Neurointerv Surg 2016; 8:547-548.

20. Leavitt SB. NSAID dangers may limit pain-relief options. PainTopics News/Research UPDATES, March 14, 2010. http://updates.pain-topics.org/2010/03/nsaid-dangers-may-limit-pain-relief.html.

21. Moore A, Wiffen P, Kalso E. Antiepileptic drugs for neuropathic pain and fibromyalgia. JAMA 2014; 312:182-183.

22. Rajaee SS, Bae HW, Kanim LE, Delamarter RB. Spinal fusion in the United States: Analysis of trends from 1998 to 2008. Spine (Phila Pa 1976) 2012; 37:67-76.

23. Pannell WC, Savin DD, Scott TP, Wang JC, Daubs MD. Trends in the surgical treatment of lumbar spine disease in the United States. Spine ] 2015; 15:1719-1727.

24. Manchikanti L, Soin A, Mann DP, Bakshi S, Pampati V, Hirsch JA. Reversal of growth of utilization of interventional techniques in managing chronic pain in Medicare population post Affordable Care Act. Pain Physician 2017; 20:551-567.

25. Manchikanti L, Pampati V, Hirsch JA. Utilization of interventional techniques in managing chronic pain in Medicare population from 2000 to 2014: An analysis of patterns of utilization. Pain Physician 2016; 19:E531-E546.

26. Manchikanti L, Hirsch JA, Pampati V, Boswell MV. Utilization of facet joint and sacroiliac joint interventions in Medicare population from 2000 to 2014: Explosive growth continues! Curr Pain Headache Rep 2016; 20:58.

27. Manchikanti L, Pampati V, Hirsch JA. Retrospective cohort study of usage patterns of epidural injections for spinal pain in the US fee-for-service Medicare population from 2000 to 2014. BMJ Open 2016; 6:e013042.

28. Manchikanti L, Kaye AM, Knezevic NN, McAnally H, Slavin KV, Trescot AM, Blank S, Pampati V, Abdi S, Grider JS, Kaye AD, Manchikanti KN, Cordner HJ, Gharibo CG, Harned ME, Albers SL, Atluri S, Aydin SM, Bakshi S, Barkin RL, Benyamin RM, Boswell MV, Buenaventura RM, Calodney AK, Cedeno DL, Datta S, Deer TR, Fellows B, Galan V, Grami V, Hansen H, Helm $S$ 2nd, Justiz R, Koyyalagunta D, Malla Y, Navani A, Nouri K, Pasupuleti R, Sehgal N, Silverman SM, Simopoulos TT, Singh V, Solanki DR, Staats PS, Vallejo R, Wargo BW, Watanabe A,
Hirsch JA. Responsible, safe, and effective prescription of opioids for chronic non-cancer pain: American Society of Interventional Pain Physicians (ASIPP) guidelines. Pain Physician 2017: 20:S3-S92.

29. Hirsch JA, Chandra RV, Pampati V, Barr JD, Brook AL, Manchikanti L. Analysis of vertebral augmentation practice patterns: A 2016 update. J Neurointer Surg 20168:1299-1304.

30. Manchikanti L, Manchikanti KN, Gharibo CG, Kaye AD. Efficacy of percutaneous adhesiolysis in the treatment of lumbar post surgery syndrome. Anesth Pain Med 2016; 6:e26172.

31. Manchikanti L, Knezevic NN, Boswell MV, Kaye AD, Hirsch JA. Epidural injections for lumbar radiculopathy and spinal stenosis: A comparative systematic review and meta-analysis. Pain Physician 2016; 19:E365-E410.

32. Grider JS, Manchikanti L, Carayannopoulos A, Sharma ML, Balog CC, Harned ME, Grami V, Justiz R, Nouri KH, Hayek SM, Vallejo R, Christo PJ. Effectiveness of spinal cord stimulation in chronic spinal pain: A systematic review. Pain Physician 2016; 19:E33-E54.

33. Jesse MK, Kleck C, Williams A, Petersen B, Glueck D, Lind K, Patel V. 3D morphometric analysis of normal sacroiliac joints: A new classification of surface shape variation and the potential implications in pain syndromes. Pain Physician 2017; 20:E701E709.

34. Manchikanti L, Hirsch JA, Falco FJ, Boswell MV. Management of lumbar zygapophysial (facet) joint pain. World J Orthop 2016; 7:315-337.

35. Manchikanti L, Benyamin RM, Falco FJ, Kaye AD, Hirsch JA. Do epidural injections provide short- and long-term relief for lumbar disc herniation? A systematic review. Clin Orthop Relat Res 2015; 473:1940-1956.

36. Manchikanti L, Hirsch JA, Kaye AD, Boswell MV. Cervical zygapophysial (facet) joint pain: Effectiveness of interventional management strategies. Postgrad Med 2016; 128:54-68.

37. Simopoulos TT, Manchikanti L, Gupta S, Aydin SM, Kim CH, Solanki DR, Nampiaparampil DE, Singh V, Staats PS, Hirsch JA. Systematic review of the diagnostic accuracy and therapeutic effectiveness of sacroiliac joint interventions. Pain Physician 2015; 18:E713-E756.

38. Cheng J, Chen SL, Zimmerman N, Dalton JE, LaSalle G, Rosenquist $R$. A new radiofrequency ablation procedure to treat sacroiliac joint pain. Pain Physician 2016; 19:603-615.

39. van Leeuwen RJ, Szadek K, de Vet H, Zurrmond W, Perez R. Pain pressure threshold in the region of the sacroiliac joint in patients diagnosed with sacroiliac joint pain. Pain Physician 2016; 19:147-154.

40. Dengler J, Kools D, Pflugmacher R, Gasbarrini A, Prestamburgo D, Gaetani P, van Eeckhoven E, Cher D, Sturesson B. 1-year results of a randomized controlled trial of conservative management vs. minimally invasive surgical treatment for sacroiliac joint pain. Pain Physician 2017; 20:537-550.

41. Kasliwal PJ, Kasliwal S. Fluoroscopy-guided sacroiliac joint injection: Description of a modified technique. Pain Physician 2016; 19:E329-E338.

42. Hegarty D. Clinical outcome following radiofrequency denervation for refractory sacroiliac joint dysfunction using the simplicity III probe: A 12-month retrospective evaluation. Pain Physician 2016; 19:E129-E135.

43. Telli $H$. Value of examination under fluoroscopy for the assessment of sacroiliac joint dysfunction. Pain Physician 2017; 20:E476-E477.

44. Chou R, Hashimoto R, Friedly J, Fu R, Dana T, Elliott S, Sul- 
livan S, Jarvik J. Pain management injection therapies for low back pain. Technology Assessment Report Prepared for Agency for Healthcare Research and Quality (AHRQ). Project ID: ESIB0813. October 29, 2014.

45. Helm II S, Racz GB, Gerdesmeyer L, Justiz L, Hayek SM, Kaplan ED, El Terany MA, Knezevic NN. Percutaneous and endoscopic adhesiolysis in managing low back and lower extremity pain: A systematic review and meta-analysis. Pain Physician 2016; 19:E245-E282.

46. Manchikanti L, Sanapati J, Benyamin RM, Atluri S, Kaye AD, Hirsch JA. Reframing the prevention strategies of the opioid crisis: Focusing on prescription opioids, fentanyl, and heroin epidemic. Pain Physician 2018; 21:309-326.

47. Farber $\mathrm{SH}$, Han JL, Elsamadicy AA, Hussaini Q, Yang S, Pagadala P, Parente B, Xie J, Lad SP. Long-term cost utility of spinal cord stimulation in patients with failed back surgery syndrome. Pain Physician 2017; 20:E797-E805.

48. Xiaochuan L, Zhong CF, Tang JH, Liang RW, Luo SJ, Huang $\mathrm{CM}$. The effectiveness and safety of selective lumbar decompression in diagnostic doubt patients: A retrospective control study. Pain Physician 2017; 20:E541-E550.

49. Manchikanti L, Falco FJE, Pampati V, Cash KA, Benyamin RM, Hirsch JA. Cost utility analysis of caudal epidural injections in the treatment of lumbar disc herniation, axial or discogenic low back pain, central spinal stenosis, and post lumbar surgery syndrome. Pain Physician 2013; 16:E129-E143.

50. Manchikanti L, Pampati V, Benyamin RM, Hirsch JA. Cost utility analysis of lumbar interlaminar epidural injections in the treatment of lumbar disc herniation, central spinal stenosis, and axial or discogenic low back pain. Pain Physician 2017; 20:219-228.

51. Manchikanti L, Pampati V, Kaye AD, Hirsch JA. Cost-utility analysis of cervical therapeutic medial branch blocks in managing chronic neck pain. Int J Med Sci 2017; 14:1307-1316.

52. Manchikanti L, Pampati V, Kaye AD, Hirsch JA. Therapeutic lumbar facet joint nerve blocks in the treatment of chronic low back pain: Cost utility analysis based on a randomized controlled trial. Korean J Pain 2018; 31:27-38.

53. Taylor RS, Ryan J, O'Donnell R, Eldabe S, Kumar K, North RB. The cost-effectiveness of spinal cord stimulation in the treatment of failed back surgery syndrome. Clin J Pain 2010; 26:463469.

54. Manchikanti L, Soin A, Mann DP, Bakshi S, Pampai V, Hirsch JA. Comparative analysis of utilization of epidural procedures in managing chronic pain in the Medicare population: Pre and post Affordable Care Act. Spine (Phila Pa 1976) 2018 [Epub ahead of print].

55. Manchikanti L, Pampati V, Benyamin RM, Hirsch JA. Declining utilization of percutaneous epidural adhesiolysis in Medicare population: Evidence-based or over-regulated? IPM Reports 2018; 2:9-18.

56. Centers for Medicare and Medicaid Services. www.cms.hhs. gov/home/medicare.Asp.

57. Vandenbroucke JP, von Elm E, Altman DG, Gøtzsche PC, Mulrow CD, Pocock SJ, Poole C, Schlesselman JJ, Egger M; STROBE Initiative. Strengthening the Reporting of Observational Studies in Epidemiology (STROBE): Explanation and elaboration. Epidemiology 2007; 18:805-835.

58. Noridian Healthcare Solutions, LLC. Local Coverage Determination (LCD). Facet Joint Injections, Medial Branch Blocks, and Facet Joint Radiofrequency Neurotomy (L34995). Revision Effective Date: 11/02/2016.

59. Noridian Healthcare Solutions, LLC. Local Coverage Determi- nation (LCD). Lumbar Epidural Injections (L34980). Revision Effective Date: 10/1/2017.

60. Manchikanti L, Helm II S, Singh V, Hirsch JA. Accountable interventional pain management: A collaboration among practitioners, patients, payers, and government. Pain Physician 2013; 16:E635-E670.

61. Department of Health and Human Services, Centers for Medicare \& Medicaid Services. 42 CFR Parts 405, 410, 411, 414, 423, and 425. Medicare Program; Revisions to Payment Policies under the Physician Fee Schedule, Clinical Laboratory Fee Schedule \& Other Revisions to Part B for CY 2014 (CMS-1600FC). Final Rule. December 10, 2013.

62. Department of Health and Human Services, Centers for Medicare \& Medicaid Services. 42 CFR Parts 403, 405, 410, 414, 425, and 498. Medicare Program; Revisions to Payment Policies under the Physician Fee Schedule, Clinical Laboratory Fee Schedule, Access to Identifiable Data for the Center for Medicare and Medicaid Innovation Models \& Other Revisions to Part B for CY 2015. Final Rule. November 13, 2014.

63. Department of Health and Human Services, Centers for Medicare \& Medicaid Services. 42 CFR Parts 414, 416, 419, 482, 486, 488, and 495. [CMS-1656-FC and IFC] Medicare Program: Hospital Outpatient Prospective Payment and Ambulatory Surgical Center Payment Systems and Quality Reporting Programs; Organ Procurement Organization Reporting and Communication; Transplant Outcome Measures and Documentation Requirements; Electronic Health Record (EHR) Incentive Programs; Payment to Nonexcepted Off-Campus Provider-Based Department of a Hospital; Hospital Value-Based Purchasing (VBP) Program; Establishment of Payment Rates Under the Medicare Physician Fee Schedule for Nonexcepted Items and Services Furnished by an Off-Campus Provider-Based Department of a Hospital; Final Rule. November 14, 2016.

64. American Recovery and Reinvestment Act of 2009 (AARA), P.L. 111-5, February 17, 2009.

65. Manchikanti L, Benyamin RM, Falco FJE, Hirsch JA. Recommendations of the Medicare Payment Advisory Commission (MedPAC) on the health care delivery system: The impact of interventional pain management in 2014 and beyond. Pain Physician 2013; 16:419-440.

66. Manchikanti L, Pampati V, Hirsch JA. Cost calculation methodology exacerbates site-of-services differential by 10 - to 18 -fold for soft tissue and joint injections in hospital outpatient departments. IPM Reports 2017; 1:183-189.

67. US Burden of Disease Collaborators. The state of US health, 1999-2010: Burden of diseases, injuries, and risk factors. JAMA 2013; 310:591-608.

68. US Burden of Disease Collaborators. The state of US health, 1990-2016: Burden of diseases, injuries, and risk factors among US states. JAMA 2018; 319:1444-1472.

69. National Institute on Drug Abuse. Overdose death rates. September 2017. www.drugabuse.gov/related-topics/trends-statistics/overdose-death-rates

70. Johnson J, Wagner J. Trump declares the opioid crisis a public health emergency. The Washington Post, October 26, 2017.

71. National Academies of Sciences, Engineering, and Medicine. 2017. Pain Management and the Opioid Epidemic: Balancing Societal and Individual Benefits and Risks of Prescription Opioid Use. Washington, DC: The National Academies Press. https://doi. org/10.17226/24781.

72. Dowell D, Haegerich TM, Chou R. CDC guideline for prescribing opioids for chronic pain--United States, 2016. MMWR Recomm Rep 2016; 6 5:1-49. 